
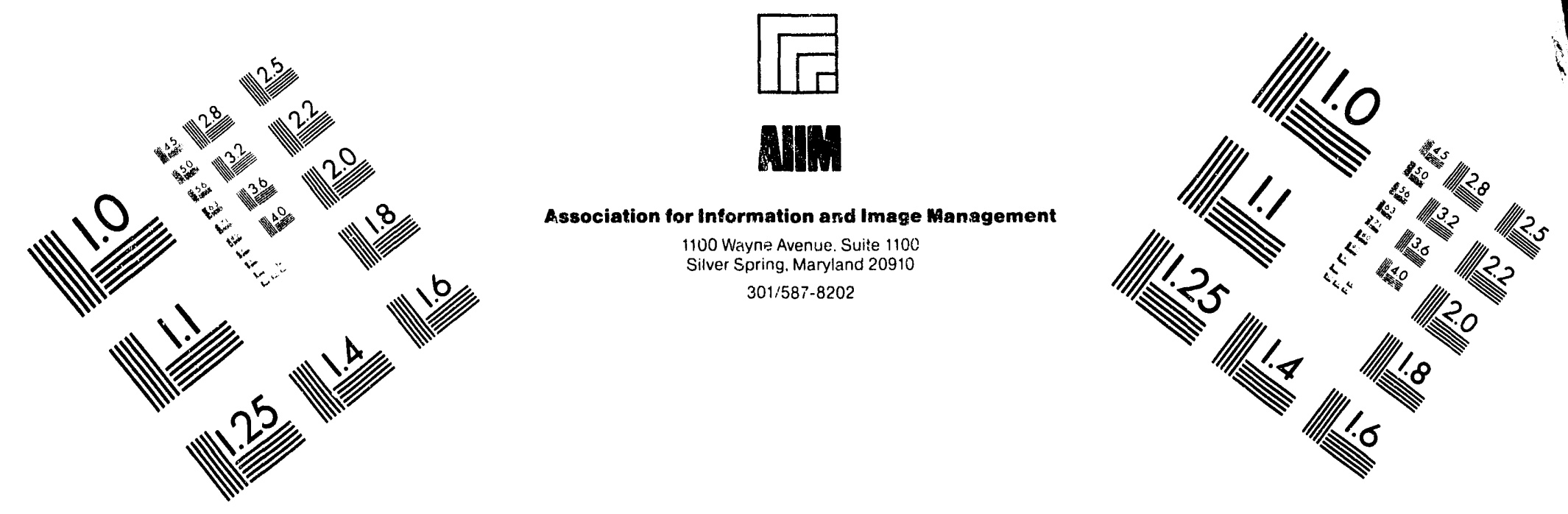

\title{
Centimeter
}

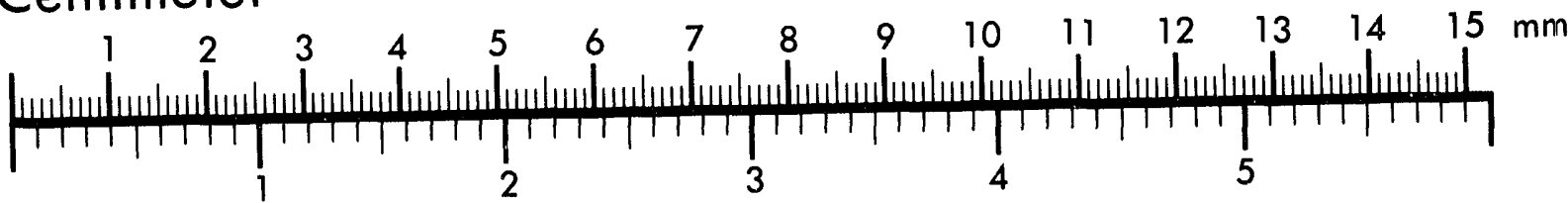
Inches
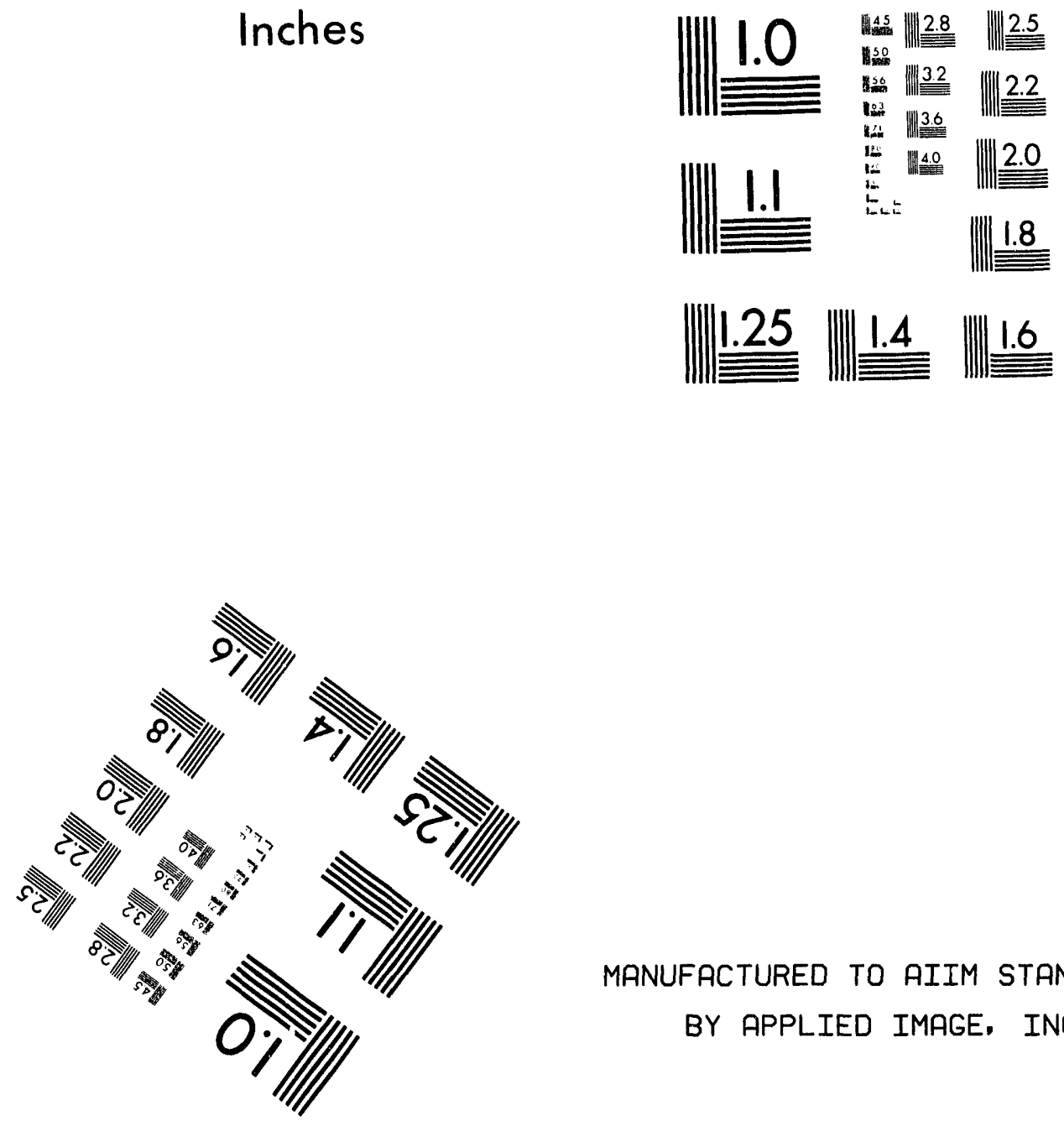

MANUFACTURED TO AIIM STANDARDS

BY APPLIED IMAGE, INC.

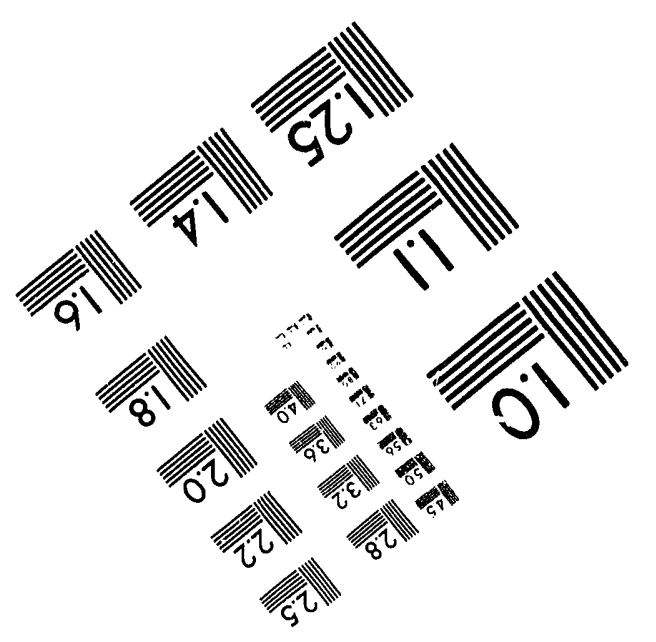



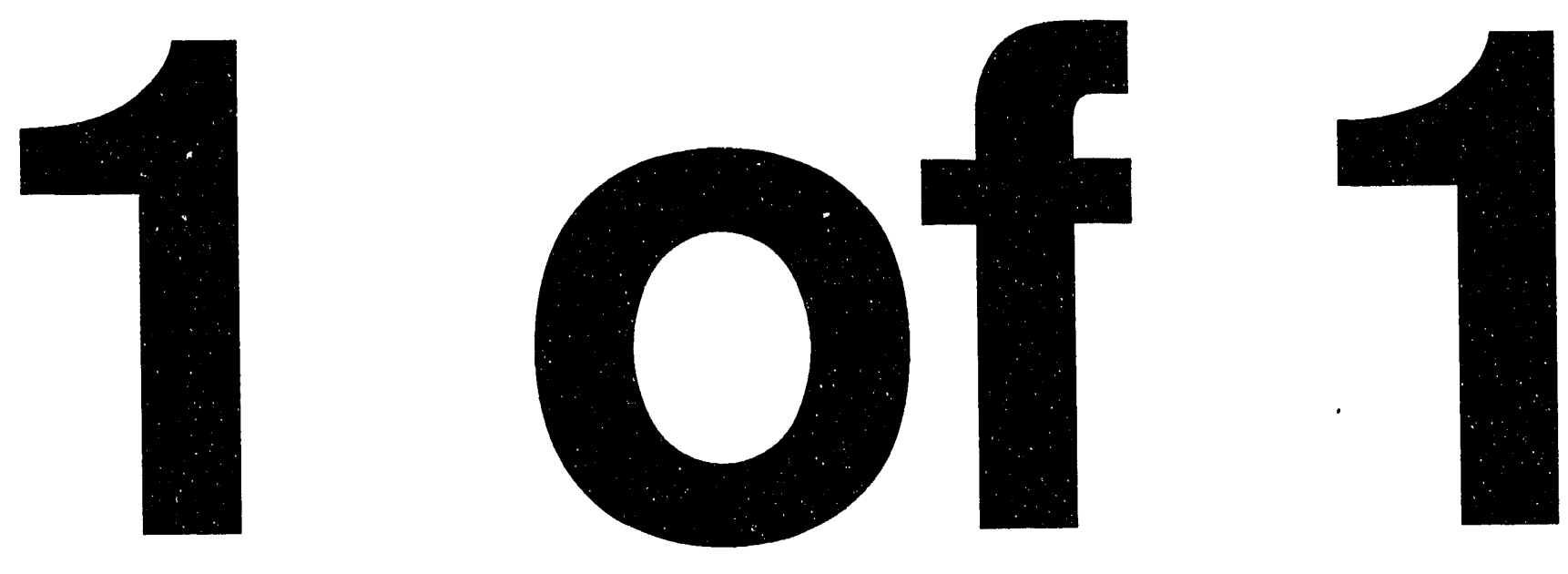


\section{Interim Progress Report - Geophysics: Decommissioning of Buildings E5974 and E5978, Aberdeen Proving Ground}

by M.G. McGinnis, L.D. MiGinnis, S.F. Miller, and M.D. Thompson

Reclamation Engineering and Geosciences Section, Energy Systems Division,

Argonne National Laboratory, 9700 South Cass Avenue, Argonne, Illinois 60439

November 1992

Work sponsored by United States Army, Aberdeen Proving Ground, Maryland 
This document is printed on recycled paper with the exception of color reproductions. 


\section{Preface}

This report is one of a series on geophysical surveys around perimeters of buildings in the Canal Creek and Westwood areas of the Edgewood section of Aberdeen Proving Ground. The series was initiated in 1991 at Building E5032, where geophysical techniques were tested and a design for the surveys was established. The series continued in 1992, when surveys of Buildings E5190, E5282, E5375, E5440, E5476, E5481, E5485, E5487, E5489, E5974, and E5978 were completed. The surveys and reports were done sequentially, with lowest building numbers being completed first. For this reason, deeper insight into the magnetic, electrical, and radar imagery characteristics of the Canal Creek area was gained with progressively increasing building numbers. A survey at the Building 103 Dump, also completed during the spring of 1992, was not specifically designed to assist building decommissioning, but it is included in the series because it was conducted by our geophysics team using techniques and procedures identical to those for the building decommissioning surveys. 


\section{Contents}

Abstract............................................................................

1 Introduction...................................................................... 1

1.1 History of Buildings E5974 and E5978 ..................................... 2

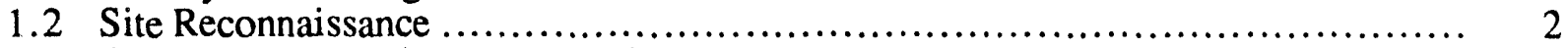

1.3 Geology and Physiographic Setting .......................................... 6

1.4 Surveys....................................................................... 7

1.5 Survey Grid and Locations of Observations..................................... 7

2 Instrumentation................................................................ 9

2.1 Magnetic Gradiometer and Cable Locator..................................... 9

2.2 Magnetometer/Gradiometer .............................................. 9

2.3 Direct-Current Electrical Resistivity Meter ..................................... 10

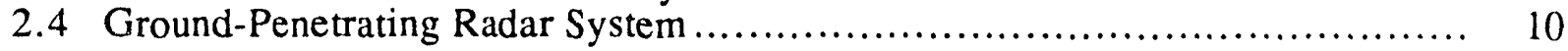

3 Geophysical Measurements and Surveys .................................... 12

3.1 Magnetometer Measurements............................................. 12

3.2 Direct-Current Electrical Resistivity Measurements............................... 12

3.3 Ground-Penetrating Radar Measurements ................................... 16

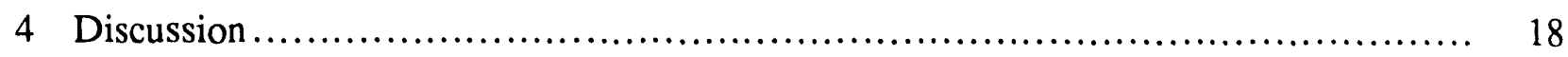

5 Conclusions ................................................................... 20

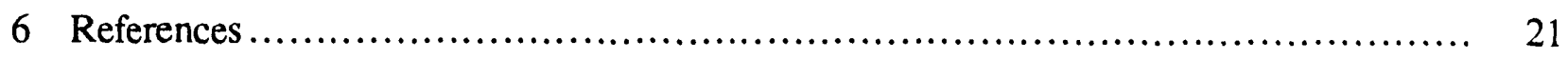

Appendix A: Electrical Depth-Sounding Curves ................................. 23

Appendix B: Ground-Penetrating Radar Line Coordinates ............................. 31

\section{Tables}

1 Lithologic Log of Borehole at Site No. 2 .......................................... 8

2 Approximate Two-Way Travel Times for Various Materials........................ 11

A.1 Location of Centers of Stations and Orientations of Electrode Arrays for Schlumberger Electrical Depth Soundings at APG ................................... 25

A.2 Resistivity Models Calculated from Electrical Depth Soundings.............................. 26 


\section{Figures}

1 General Site Map of the Westwood Area, Aberdeen Proving Ground, Md............. 3

2 General Location Map of Westwood Area Buildings E5974 and E5978 ............... 4

3 Geophysical Survey Boundaries for Buildings E5974 and E5978 .................. 5

$4 \quad$ Map of Total Magnetic Field Intensity for Buildings E5974 and E5978 ............... 13

$5 \quad$ Apparent Resistivity Map of Buildings E5974 and E5978 _......................... 14

6 South-North Ground-Penetrating Radar Profile for the Area West of Building E5974 .............................................................. 17

$7 \quad$ Magnetics/Resistivity Overlay Map of Buildings E5974 and E5978 _................ 19

A.1 Electrical Depth-Sounding Curve near Building E5282 .................................. 27

A.2 Electrical Depth-Sounding Curve near Building E5440................................... 28

A.3 Electrical Depth-Sounding Curve near Building E5481.................................... 29

A.4 Electrical Depth-Sounding Curve near Building E5974.................................... 30 


\title{
Interim Progress Report - Geophysics: Decommissioning of Buildings E5974 and E5978, Aberdeen Proving Ground
}

\author{
by \\ M.G. McGinnis, L.D. McGinnis, \\ S.F. Miller, and M.D. Thompson
}

\begin{abstract}
Buildings E5974 and E5978, located near the mouth of Canal Creek, were among 10 potentially contaminated sites in the Westwood and Canal Creek areas of the Edgewood section of Aberdeen Proving Ground examined by a geophysical team from Argonne National Laboratory in April and May of 1992. Noninvasive geophysical surveys, including the complementary technologies of magnetics, electrical resistivity, and ground-penetrating radar, were conducted around the perimeters of the buildings to guide a sampling program prior to decommissioning and dismantling. The magnetic anomalies and the electrically conductive areas around these buildings have a spatial relationship similar to that observed in lowlying sites in the Canal Creek area; they are probably associated with construction fill. Electrically conductive terrain is dominant on the eastern side of the site, and resistive terrain predominates on the west. The smaller magnetic anomalies are not imaged with ground radar or by electrical profiling. The high resistivities in the northwest quadrant are believed to be caused by a natural sand lens. The causes of three magnetic anomalies in the high-resistivity area are unidentified, but they are probably anthropogenic.
\end{abstract}

\section{Introduction}

Aberdeen Proving Ground (APG), in the state of Maryland, is currently managing a comprehensive Installation Restoration Program involving more than 360 solid-waste managing units contained within 13 study areas. The Edgewood area and two landfills in the Aberdeen area appear on the National Priority List under the Comprehensive Environmental Response, Compensation, and Liability Act. Therefore, APG has entered into an Interagency Agreement with the U.S. Environmental Protection Agency to address the listed areas.

A report by EAI Corporation (1989) included a list of 29 potentially contaminated buildings in the Edgewood area. Sixteen of the buildings contain known contaminants, nine buildings contain unknown contaminants, and four of the buildings are potentially clean. The EAI report recommended that a sampling and monitoring program be established to verify contamination levels in and around each building. Thirteen of the potentially contaminated buildings are in the 
West Branch of the Canal Creek area and two are in the Westwood area. All are potential sources of volatile organic compounds.

Aberdeen Proving Ground is proceeding with a program to decommission the buildings, which will eliminate the actual or potential release of contaminants into the environment of the West Branch of the Canal Creek and other sites within the Edgewood area. Argonne National Laboratory has been assigned the task of developing a plan and scope of work for the proposed decommissioning. Argonne has determined that the first step in this decommissioning process, where it is technically feasible, should be a noninvasive geophysical survey around building exteriors.

The two Westwood area buildings, E5974 and E5978, located $50 \mathrm{ft}$ apart approximately $3,200 \mathrm{ft}$ due west of the mouth of Canal Creek (Figure 1), were surveyed in the first series of building studies. These buildings were included early in the geophysical surveying program because their site is relatively undisturbed and could provide an opportunity to test geophysical field methods without undue surface interference. The buildings are located on Hog Point Road, which traverses an upland area separating the Reardon Inlet wetlands from the north bank of the Gunpowder River (Figure 2). Discussions of the two buildings are contained in one report because they have related histories as well as locations. Figure 3 shows the boundaries of the study area for these buildings.

\subsection{History of Buildings E5974 and E5978}

According to records examined by EAI Corporation (1989), Building E5974 was constructed in 1960. The records state that Building E5978 was built in 1953, but a contradictory statement in the historical narrative claims that it was constructed in 1960. Building E5974 was heated and served primarily as a field office, whereas Building E5978 was used primarily for storage. A metal furnace exhaust is centrally located on the south-facing roof of Building E5974. The buildings each measure $16 \times 16 \mathrm{ft}$ and are constructed on wood foundations and floors with wood frame walls. The roof of Building E5974 is covered with asphalt shingles, whereas that of Building E5974 is rolled roofing. The buildings were constructed for use as field offices during training and testing and were placed on inactive status in 1976.

\subsection{Site Reconnaissance}

The geophysical survey program for Buildings E5974 and E5978 was designed on the basis of results from a similar study completed between April 8 and April 19, 1991, for Building E5032 (McGinnis and Miller 1991), which is located in the Canal Creek area. The initial evaluation was enhanced by a visit to the site in November 1991 and by inspection of aerial photos. 


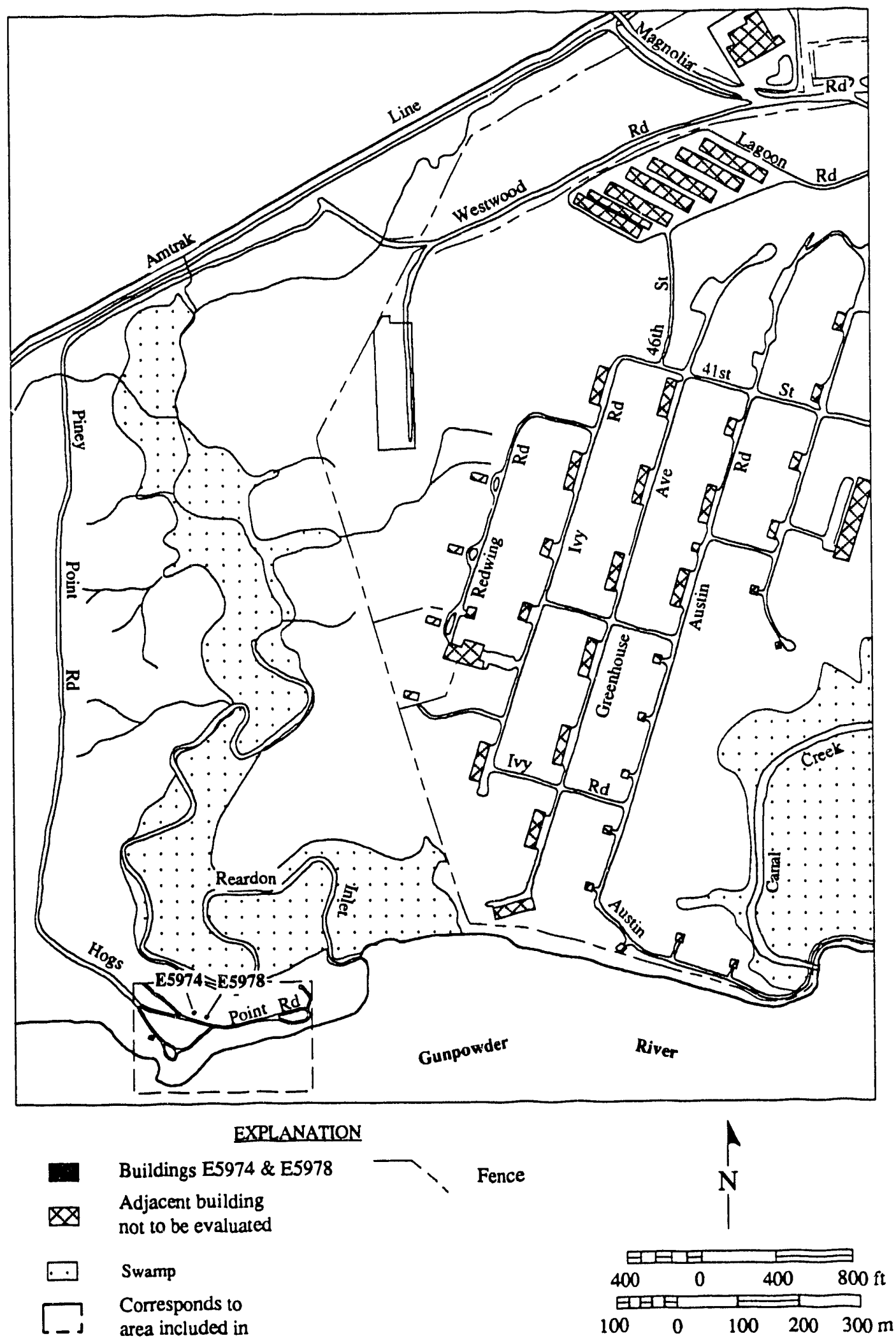

Figure 2

FIGURE 1 General Site Map of the Westwood Area, Aberdeen Proving Ground, Md. 


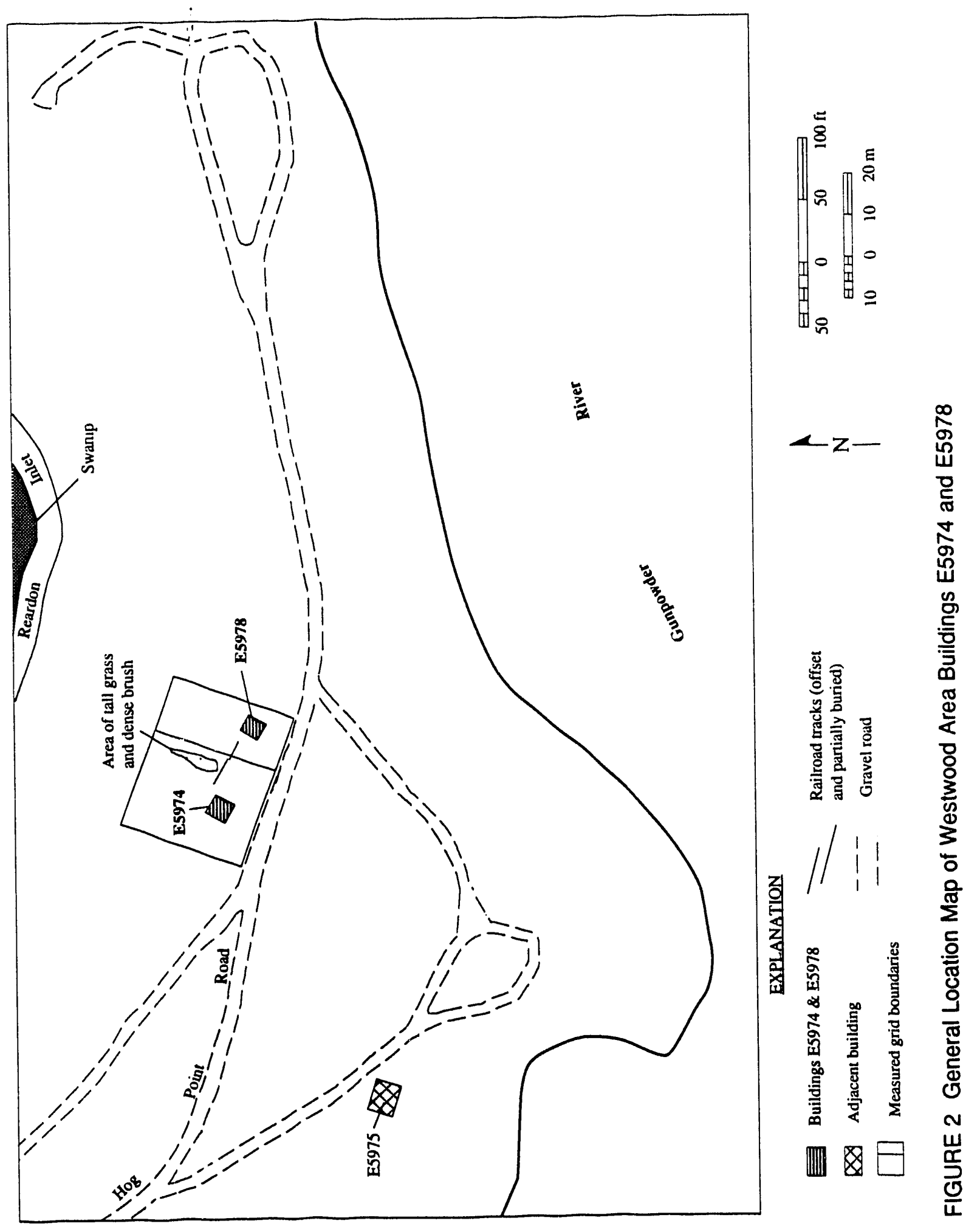



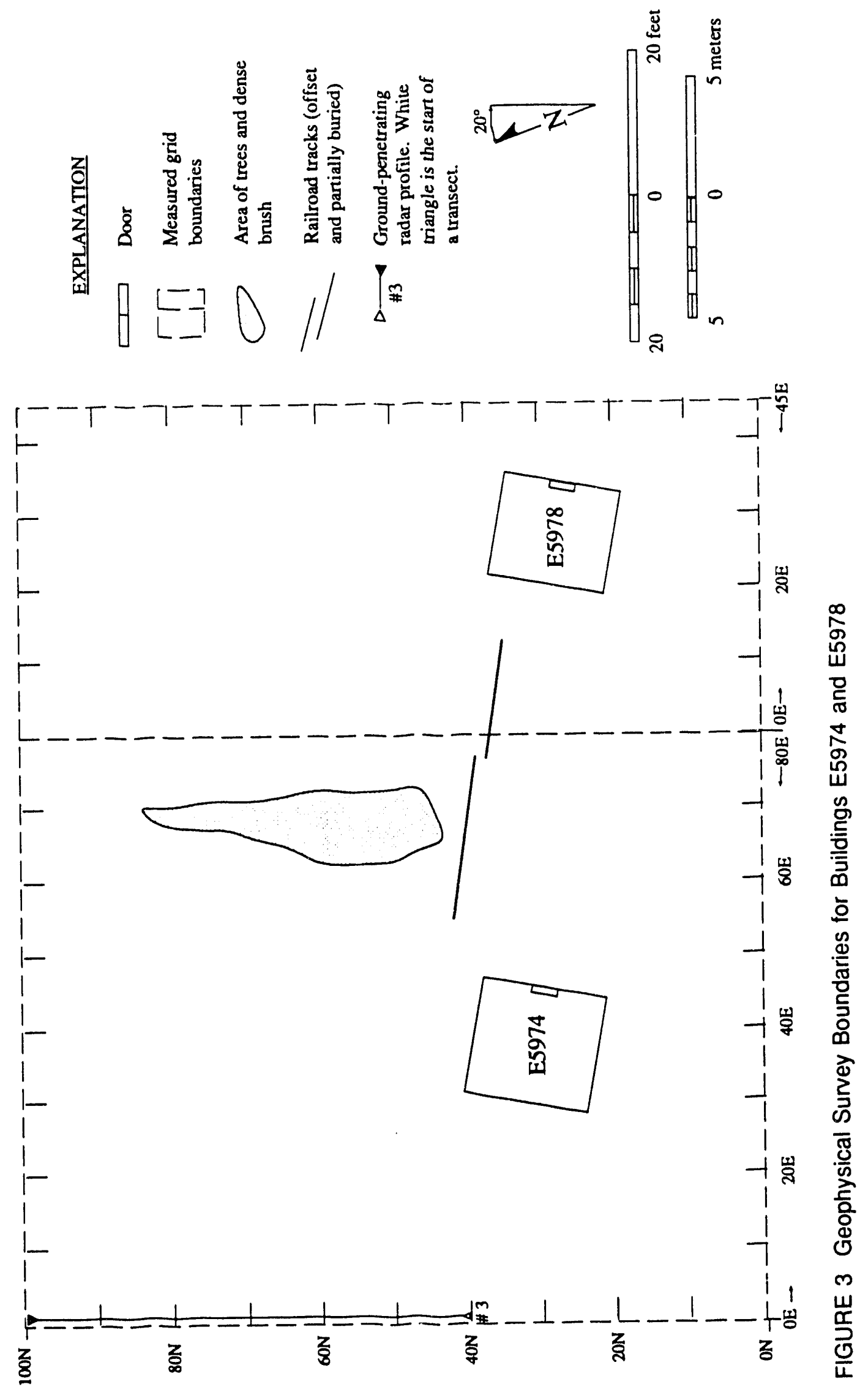
The buildings are located on gently sloping terrain about $250 \mathrm{ft}$ north of the Gunpowder River and 15-20 ft north of Hog Point Road, in an area used by local fisherpeople. The site is currently covered with tall grass. An elongate cluster of mature trees and bushes is centrally located immediately north of the two buildings. Three surface depressions, each measuring several feet in diameter, were observed north of the buildings, with the largest about $50 \mathrm{ft}$ north of Building E5978. A pole for a power line is located about $45 \mathrm{ft}$ southwest of Building E5974. An abandoned 500-gal heating-oil tank is lying on the ground outside the west wall of Building E5974. Partially buried steel railr Jad tracks are located between the two buildings.

In addition to surface, conditions at the site, subsurface characteristics were considered in planning the geophysical sirveying:

1. Surficial sediments consist of estuarine silts, sands, and clays that have intermediate rusistivities and are nonmagnetic. The underlying soil properties are expected to vary both horizontally and vertically in the proximity of the site, depending on naturally occurring conditions and on the presence of building excavations and operations.

2. Buildings and other attributes of the Edgewood section of Aberdeen, such as radio and radar transmissions, will contribute to interference of magnetic and electrical fields and will cause electromagnetic surveying (an easily applied, low-cost method that is frequently used to identify buried conductive objects) to be generally inapplicable (AEHA 1989).

3. Multiple sources, such as iron-rich magnetized objects, nonmagnetic objects, subsurface channels containing contaminants, and plumes of contaminants of variable resistivity, may be present in the subsurface.

Multiple working technologies were utilized in the program design to mitigate interference and to either directly detect or provide inferential data on subsurface characteristics.

\subsection{Geology and Physiographic Setting}

The Westwood site is located in the topographically low and flat terrain of the Coastal Plain physiographic province and is underlain by alluvial and estuarine sands, silts, and clays. A thin veneer of sediments of the Talbot Formation of Pleistocene age overlies unconsolidated sediments of the Potomac Group of Cretaceous age (Oliveros and Gernhardt 1988). The water table is less than $10 \mathrm{ft}$ from the surface.

Subsurface stratigraphy at the site is probably similar to that observed in boreholes in the Canal Creek area as part of a hydrogeologic study by the U.S. Geological Survey (Oliveros and 
Gernhardt 1989). The nearest well was site No. 2, about $4,000 \mathrm{ft}$ east of the site. The descriptive $\log$ for this borehole is given in Table 1.

\subsection{Surveys}

The geophysical phases of the building decommissioning programs at Buildings E5974 and E5978 were carried out as planned during the period April 6 to May 8, 1992. Geophysical measurements conformed to the work plan (McGinnis et al. 1992), which called for magnetics, horizontal direct-current electrical resistivity (DCER), and ground-penetrating radar (GPR) surveys. An addition to the plan was the use of a magnetic gradiometer/metal detector to ensure detection of anomalies between survey profiles and grid stations. Seismic imaging information was not required at the site. Each technique had its own specific objectives:

- Gradiometer/metal detector sweep - to provide a rapid, $100 \%$ sweep of the site;

- Magnetometer measurements - to determine the location of such buried, ironrich objects as tanks, pipes, debris, etc.;

- Horizontal DCER survey - to establish the regional conductive nature of the subsurface and to identify contaminant plumes to depths of approximately $10 \mathrm{ft}$; and

- Ground-penetrating radar survey - to determine the geometry of, and to find the approximate depth to, buried objects.

The following data were acquired during field operations: (1) nonpermanent ground markings of magnetic objects, (2) 614 magnetic observations, (3) 577 horizontal DCER observations, and (4) 3,117 (linear) ft of GPR profile along 42 lines. Field operations required a total of three days for a four-person team. On-site personal computers (both notebook and desktop), interactive software, field equipment designed specifically for Aberdeen, and an allterrain vehicle were used to expedite data acquisition and processing.

\subsection{Survey Grid and Locations of Observations}

Prior to geophysical surveying, wooden stakes were placed at the site corners for each building to mark the area to be surveyed. Grid spacing was at 5-ft intervals. The zero coordinate was at the southwest corner of each surveyed area. Positive numbers were measured north and east of the zero coordinate, whereas negative coordinates were measured south and west (see Figure 3). The buildings are not perfectly aligned north-south and east-west. 
TABLE 1 Lithologic Log of Borehole at Site No. 2

\begin{tabular}{|c|c|c|}
\hline Description ${ }^{a}$ & $\begin{array}{l}\text { Depthb } \\
(f t)\end{array}$ & $\begin{array}{l}\text { Thickness } \\
\qquad(\mathrm{ft})\end{array}$ \\
\hline Soil zone, brown & 2.0 & 2.0 \\
\hline Sand, clayey, orange and gray-brown mottled, gravel & 4.0 & 2.0 \\
\hline Clay, sandy-brown, wet & 6.2 & 2.2 \\
\hline Sand, clayey, light gray, poorly sorted [vfU-mL] & 10.0 & 3.8 \\
\hline Clay, gray; with thin sand lenses & 12.0 & 2.0 \\
\hline Sand and gravel, white, orange-stained & 36.9 & 24.9 \\
\hline Sand, light gray, black stained & 40.0 & 3.1 \\
\hline Sand and gravel, white, coarse & 48.0 & 8.0 \\
\hline Clay, silty, brick-red and gray miuttling, friable & 58.0 & 10.0 \\
\hline Sand, silty, light gray, well-sorted [fL-fU], micaceous & 67.7 & 9.7 \\
\hline Clay, sandy, red, brown, yellow, and gray mottled; friable & 68.0 & 0.3 \\
\hline Sand, silty, light gray, poorly sorted [fL-fU] & 68.7 & 0.7 \\
\hline Clay, silty, mottled as before, friable, lignitic, dense & 82.2 & 13.5 \\
\hline Sand, clayey, light gray, poorly sorted & 83.0 & 0.8 \\
\hline $\begin{array}{l}\text { Clay, silty, mottled as before, friable, micaceous; with thin } \\
\text { gray sand lenses }\end{array}$ & 92.0 & 9.0 \\
\hline No sample & 96.0 & 4.0 \\
\hline $\begin{array}{l}\text { Clay, silty, mottled as before, friable, micaceous; with thin } \\
\text { gray sand lenses }\end{array}$ & 98.0 & 2.0 \\
\hline No sample & 110.0 & 12.0 \\
\hline Sand, silty, light gray [fU.mL]; with thin gray clay lenses & 138.0 & 28.0 \\
\hline $\begin{array}{l}\text { Sand, light gray, clean, well-sorted [mL-cL], lignitic; with } \\
\text { small gravel }\end{array}$ & 151.1 & 13.1 \\
\hline No sample & 164.0 & 12.9 \\
\hline Clay, sandy, dark brown, maroon and gray, friable & 165.2 & 1.2 \\
\hline No sample & 176.0 & 10.8 \\
\hline Clay, silty, dark gray, friable, micaceous & 176.5 & 0.5 \\
\hline Sand, silty, silver-gray [fL] micaceous & 179.9 & 3.4 \\
\hline Sand, light gray, clean, well-sorted [mU] & 181.2 & 1.3 \\
\hline
\end{tabular}

a Codes enclosed in brackets at selected horizons refer to color designations as specified in the Munsell Soil Color Charts (1975).

b Beginning at $16 \mathrm{ft}$, sample cores were taken every other $2 \mathrm{ft}$; therefore, the data were interpolated unless more than $2 \mathrm{ft}$ of sample were missing.

Sourt

Source: Oliveros and Gernhardt (1989). 


\section{Instrumentation}

\subsection{Magnetic Gradiometer and Cable Locator}

The Schonstedt MAC-51B magnetic gradiometer and cable locator is a dual-mode instrument designed for detecting shallow buried iron and steel objects and tracing underground cables and pipes. The system consists of a transmitter and a dual-function receiver designed to detect anomalous magnetic gradients.

Maps or models are not constructed from observations made with the MAC 51B because it is not a calibrated system. The MAC-51B is an audio device used only for rapid detection of magnetic materials for further analysis with complementary instrumentation. Anomalies are identified by changes in sound amplitude and frequency and are marked on the ground surface prior to the initiation of other surveys. If anomalies detected with the MAC-51B cannot be verified with the magnetometer (see section on magnetometer), the anomaly is assumed to be insignificant.

Application of the MAC-51B in its receiver mode was the first geophysical operation following establishment of survey limits. A qualitative description of the site with $100 \%$ ground coverage is achieved using the gradiometer, whereas the results obtained with other techniques, although more quantitative, are spatially limited to single-point, survey-grid observations or to continuous readings along spaced profiles.

\subsection{Magnetometer/Gradiometer}

Magnetics is the best technique for identifying such buried magnetized objects as tanks, drums, and small iron-rich debris. The EDA OMNI IV magnetometer/gradiometer is a total-field, proton-precession, microprocessor-based instrument that can also measure magnetic gradients. Internal software permits down-loading directly into an on-site computer.

Total-field magnetic observations were made at 5-ft and smaller intervals along profiles, yielding a grid of data that was contoured using the SURFER V. 4.0 software by Golden, Inc. (1991), to identify potential sources of contaminants and to distinguish them from background. The SURFER software was incorporated into the field acquisition procedure, so that daily map outputs were available for observation and interpretation.

The earth's magnetic field is reasonably well-known at a given time and place, although small changes in the field occur continuously, with larger changes, occurring during magnetic storms. To adjust for field changes, the instrument has internal calioration to correct observations made at cross lines and base stations. Repeat readings were used to correct data for diurnal field fluctuations. 


\subsection{Direct-Current Electrical Resistivity Meter}

Data on the electrical properties of soils at APG may permit detection of abnormally conductive or nonconductive liquid or solid contaminants. Most of the electrical properties of sedimentary materials are a product of the chemistry of interstitial fiuids. Consequently, resistivity data can be diagnostic and complement magnetic and radar measurements. Direct-current electrical resistivity measurements have been incorporated into the APG study to take the place of conductivity measurements using electromagnetic methods typically made for investigations of this type. Electromagnetic methods could not be used because of the previously isported interference problems (AEHA 1989).

Resistivity equipment used on the Aberdeen project consisted of an ABEM Terrameter and Booster, model SAS $300 \mathrm{C}$, that utilized a variety of electrode configurations. A modified, eightelectrode Wenner array was the configuration selected, and it was towed behind an all-terrain vehicle. Profiles were coincident with GPR and magnetic lines, and data were recorded at $5-\mathrm{ft}$ intervals along the lines. Consistency of repeat observations over a test profile and over known electrical anomalies provided assurance of relative data quality and variations. Data were contoured using SURFER software as described in the magnetics section.

Electrical depth-sounding curves using a Schlumberger electrode array were also determined in the Edgewood area to add a three-dimensional view to horizontal mapping. Each sounding curve was interpreted using the RESIX PLUS software package written by Interpex (1988). Resistivities of undisturbed soils were comparable with those observed at Building E5032, which averaged $60 \Omega-\mathrm{m}^{*}$ (See Appendix A for further information.)

\subsection{Ground-Penetrating Radar System}

Ground-penetrating radar surveying was accomplished using a Geophysical Survey Systems, Inc. (GSSI), model SIR-3 radar connected to a transceiver with a cable approximately $300 \mathrm{ft}$ long. Data were recorded on a digital audio tape to permit playback and computer processing. The control unit/graphic recorder was located in the transport vehicle. An IBMcompatible processing computer was located in a field office, so that the radar operator could down-load, check data-tape quality, and do preliminary processing after a day's run. Radan I computer software written by GSSI was used for processing the GPR data.

Wave-velocity characteristics of materials to be found at the Aberdeen/Edgewood area were derived from buried objects at known positions. Internal calibration was run at least twice each day to ensure that the graphic record of the range setting was consistent. Studies conducted during the 1991 field season suggested wave velocities of $6-7 \times 10^{-9} \mathrm{~s} / \mathrm{ft}$ for near-surface sediment at

* Resistivity data acquisition and processing were done using the metric system of measurement. To convert from meters to feet, multiply values given in meters by 3.28 . 
Aberdeen; however, characteristics vary with the heterogeneity of the subsurface. Typical wave velocities for different materials are shown in Table 2.

Ground-penetrating radar is probably the best method available to determine depth and geometry of objects buried near the surface. The weakness of the method is its limited depth of exploration due to wave-propagating constraints imposed by the electrical properties of soils. The maximum depth of penetration with GPR at Buildings E5974 and E5978 was approximately $8 \mathrm{ft}$ below the ground surface.

TABLE 2 Approximate Two-Way Travel Times for Various Materials

\begin{tabular}{|c|c|c|c|}
\hline Material & $\begin{array}{l}\text { Two-Way } \\
\text { Travel Time } \\
\left(10^{-9} \mathrm{~s} / \mathrm{ft}\right)\end{array}$ & Material & $\begin{array}{l}\text { Two-Way } \\
\text { Travel Time } \\
\left(10^{-9} \mathrm{~s} / \mathrm{ft}\right)\end{array}$ \\
\hline Air & 2 & Marshy forested land & 7 \\
\hline Fresh water & 18 & Rich agricultural land & 8 \\
\hline Sea water & 18 & Fresh-water ice & 4 \\
\hline Sand (dry) & 4.5 & Granite (dry) & 4.5 \\
\hline Sand (saturated) & 11 & Limestone (dry) & 5 \\
\hline Silt (saturated) & 6 & Concrete & 5 \\
\hline Clay (saturated) & 6 & Asphalt & $4-5$ \\
\hline Dry, sandy, coastal land & 6 & & \\
\hline
\end{tabular}

Source: Geophysical Survey Systems, Inc. (1987). 


\section{Geophysical Measurements and Surveys}

\subsection{Magnetometer Measurements}

Total magnetic field observations were made at 614 stations for use in constructing the magnetic map shown in Figure 4. Station spacing was normally $5 \mathrm{ft}$; however, where the presurvey gradiometer scan identified anomalous zones, stations were read at intervals as small as $1 \mathrm{ft}$. Magnetic field values displayed in Figure 4 were obtained by dividing observed values by 100 . Various contour intervals were used to display low- and high-amplitude magnetic anomalies without loss of visual clarity: a 200-gamma contour interval for the magnitude range from 53,000 to 55,000 gamma; a 500-gamma contour interval for magnitudes between 55,000 and 56,000 gamma; and a 600-gamma contour interval from 56,000 to 58,200 gamma. Loweramplitude features observed in much of the area are enhanced without loss of character in the higher-amplitude anomalies.

Fifteen magnetic anomalies are randomly distributed over the area surveyed, with most of the anomalies in the eastern half of the site. A large, high-amplitude anomaly, located between the two buildings, is produced by two partially buried steel railroad tracks and other surface debris. The presence of these anomalies indicates that the site is not pristine, but that it contains unidentified magnetic objects. Most of the unidentified magnetic objects observed in Figure 4 are one-station anomalies. However, excluding the magnetic noise due to surface debris lying between Buildings E5974 and E5978, five anomalies are multistation features that may ultimately require closer scrutiny. Three of these anomalies lie in the northwest quadrant; the fourth is centered at $60 \mathrm{~N}, 10 \mathrm{E}$ (Building E5978 coordinates; refer to Figure 4); and the fifth is a magnetic extension south from Building E5978. Most of the smaller anomalies are probably associated with construction fill used to provide a level grade in the field-office area.

\subsection{Direct-Current Electrical Resistivity Measurements}

The apparent resistivity map, shown in Figure 5, was constructed using DCER observations made at 577 stations. The electrode spacing was $2 \mathrm{~m}$, a configuration that provides an average resistivity for materials lying between the surface and a depth of about $10 \mathrm{ft}$. Lack of a test boring at the site results in interpretations regarding near-surface stratigraphy that must remain speculative; however, the proximity of the site to the Gunpowder River on the south and the Reardon Inlet and wetland to the north, would suggest a stratigraphy similar to that in the Canal Creek area. Construction fill may have been brought to the site to raise the road grade and to improve access around the field offices. Grade materials are underlain by alluvium and estuarine deposits consisting of sands, silts, and organic clays.

From previous work (McGinnis and Miller 1991), background resistivities for these finegrained, organic-rich, clayey materials were found to range from 50 to $150 \Omega-\mathrm{m}$. As a basis for 
วุำ

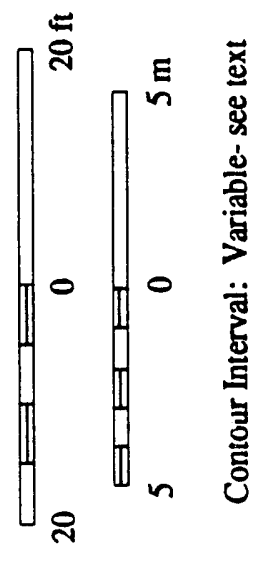

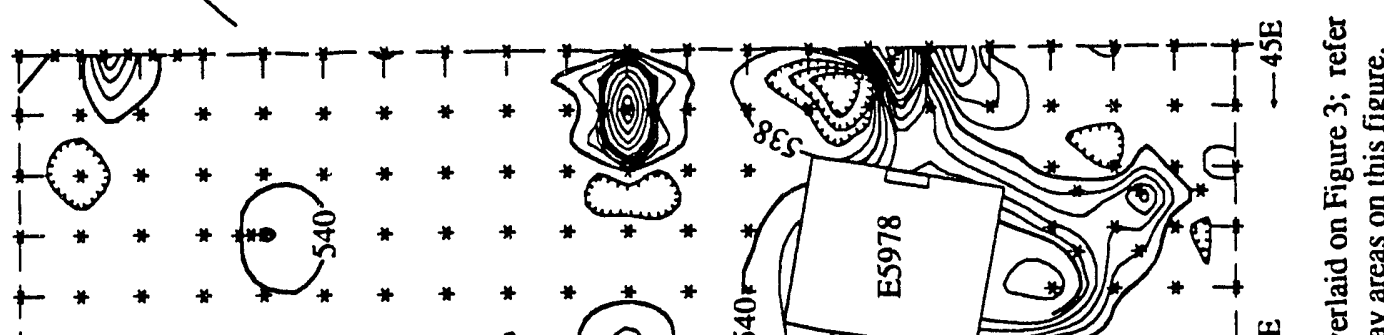
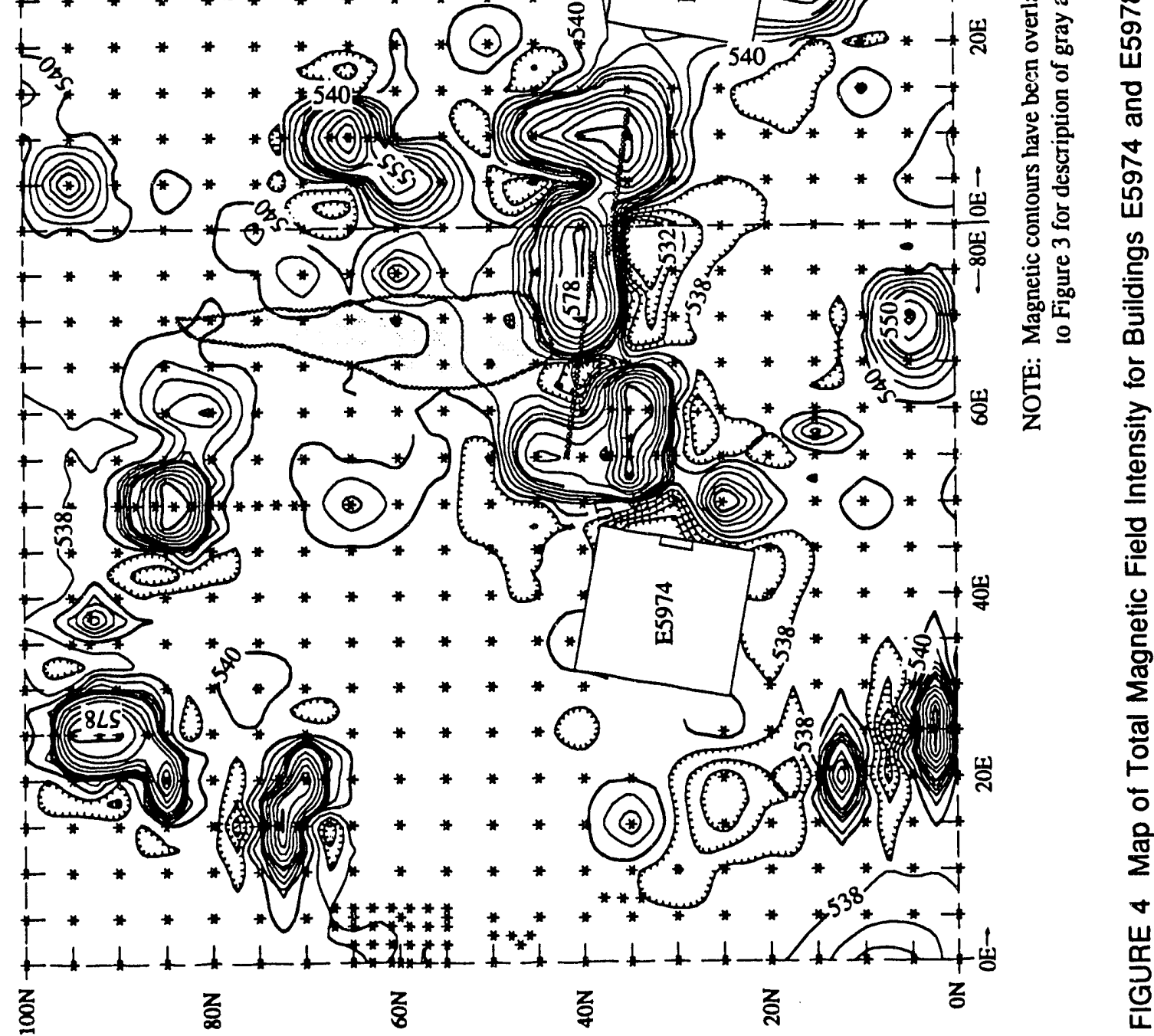
격

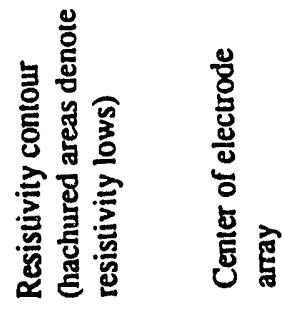

然子
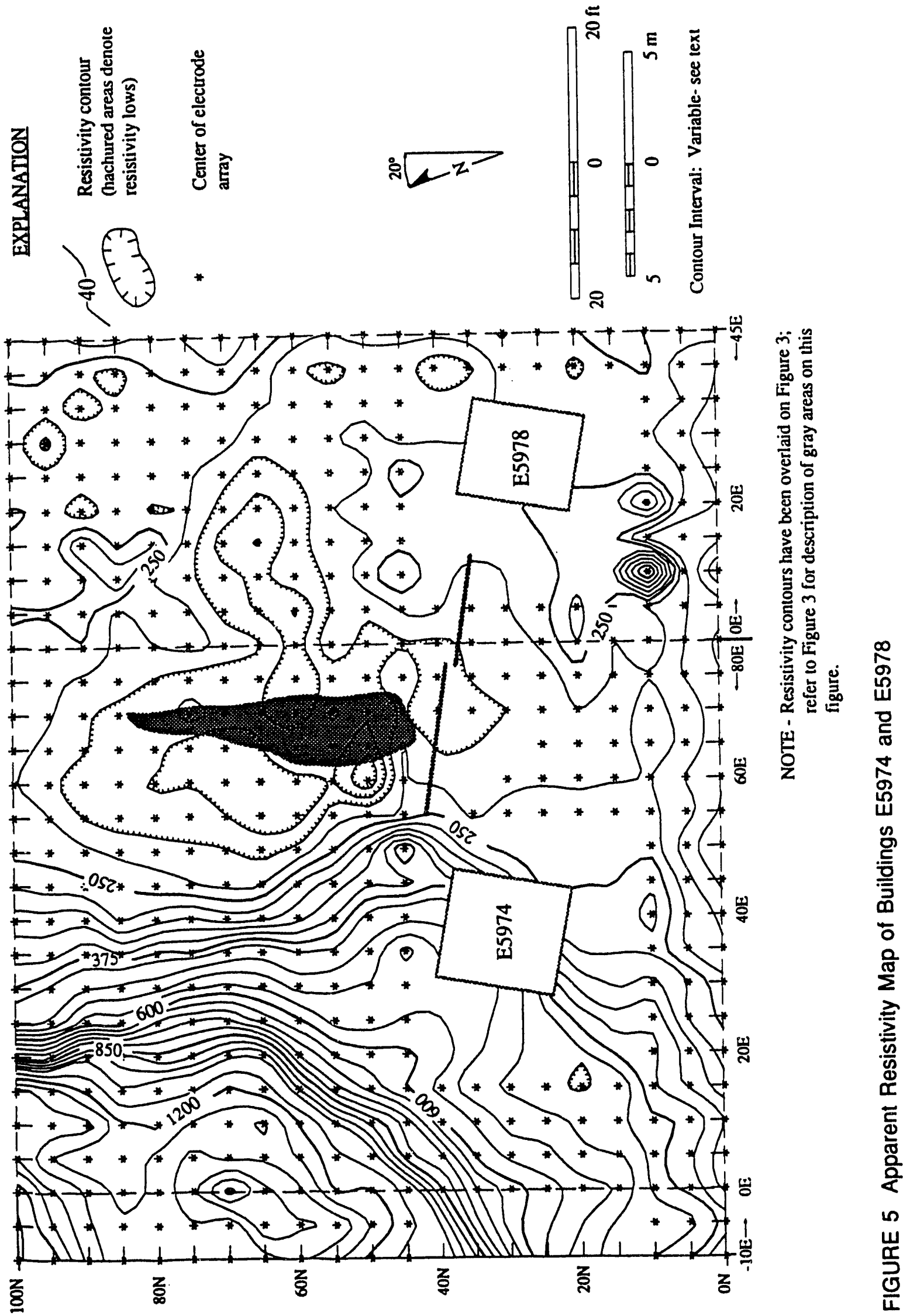
comparison with minima observed in other areas, a value of $6 \Omega$-m was observed over the "barespot," a suspected buried tank at Building E5032, and high resistivities of up to $180 \Omega$-m were observed in the vicinity of a suspected old railroad bed.

Keller and Frischknecht (1970) summarize soil-resistivity data from hundreds of measurements made near radio stations in the United States. They report the average value in Atlantic Coast areas to be $340 \Omega-\mathrm{m}$, with a range from 182 to $645 \Omega-\mathrm{m}$. The resistivity determined at a radio station represents "the average value for rocks over an area of a few square miles about the broadcasting station to a depth of about a hundred feet." Resistivities observed in the Westwood area are within the range published by Keller and Frischknecht, except for the large, elliptical, high-resistivity area in the northwest quadrant.

Electrical depth-sounding curves collected for background in the Edgewood area indicate that resistivity values normally decrease with depth, probably due to increasing salinity and changing lithologies in the Cretaceous sediments. Where anomalous materials are present, this generalization is not valid.

An electrical depth-sounding station centered at 100N,-10E (Building E5974 coordinates) is shown in Appendix A (see Figure A.4). The sounding station was oriented along a NW-SE line and was located on an open, grass-covered rise. Inversion of the curve results in a four-layer electrical model. Resistivities are within the expected range except for layer two $(3,055 \Omega-\mathrm{m})$, which ranges in depth from 0.9 to $3.6 \mathrm{~m}$. This electrical unit is probably the source of the highresistivity zone in the northwest corner of the map in Figure 5 . The lower resistivity of $123 \Omega-\mathrm{m}$ for layer four, at a depth of $50 \mathrm{~m}$, may mark the top of pre-Cretaceous basement.

A variable contour interval was used in construction of the resistivity map shown in Figure 5 because of the extreme range in values: from a minimum of $150 \Omega-\mathrm{m}$ in the northcentral part of the area to a maximum of $1,815 \Omega-\mathrm{m}$ in the northwest. The contour interval is $25 \Omega-\mathrm{m}$ between 150 and $400 \Omega-\mathrm{m} ; 50 \Omega-\mathrm{m}$ from 400 to $1,000 \Omega-\mathrm{m}$; and $100 \Omega-\mathrm{m}$ from 1,000 to $1,800 \Omega-\mathrm{m}$.

The resistivity map is unique in comparison with maps associated with buildings in the Canal Creek area. Small anomalies are absent, and large anomalies are defined by smooth, continuous contours. The electrical character of the soils probably reflects the lack of intensive construction activity around the foundations of the buildings, which resulted in more natural soil conditions. The map is dominated by a high-resistivity zone in the northwest quadrant. The high resistivities are probably due to the naturally high values characteristic of fresh-water wetlands, as well as the fact that very dry conditions existed for several months prior to the resistivity survey. Lower resistivities in the area between the two buildings may be produced by fill materials. 


\subsection{Ground-Penetrating Radar Measurement:}

Ground-penetrating radar measurements around the perimeters of the buildings were made over 3,117 ft of traverse along 42 individual profiles, coincident with the magnetic and resistivity profiles. The GPR data were collected separately for each building and are listed in two separate tables in Appendix B. The lines are numbered in sequence, along with the beginning and ending positions relative to the grid survey. Prior to running the production lines for the survey, replicate runs were made to determine which of the three transceivers - the 80-, 300-, sr 500- $\mathrm{MHz}$ antenna - was best suited to study the terrain surrounding the site. The transceiver providing the best penetration and resolution of buried objects was the $300-\mathrm{MHz}$ unit. Different range settings were also tested over the same transect to determine the optimum resolution and depth of penetration. A range setting of $90 \mathrm{~ns}$ was used for the entire survey at a scan rate of 16 scans per second. Good penetration was observed over most of the site, with resolution down to about $8 \mathrm{ft}$ below the ground surface.

Without verification by another technique or by passing the antenna over a known buried object, characteristics of radar anomalies may only be inferred. However, where GPR anomalies coincide with magnetometer or electrical anomalies, a more specific interpretation is possible. GPR images are heavily dependent on the state of the ground surface. The surface around the perimeters of Buildings E5974 and E5978 was primarily a grassy terrain, which is generally accompanied by a chaotic radar image. Concrete and asphalt surfaces support a more coherent subsurface image. Passing the antenna over a steel cover results in a strongly ringing image.

A significant GPR anomaly can be seen in Figure 6, which shows a south-north profile along the western edge of the survey area. (The vertical scale is shown on the right side of the profile, whereas lines are marked at $10-\mathrm{ft}$ intervals for the horizontal scale.) This profile was computer-enhanced by means of deconvolution to emphasize the dipping reflector centered at coordinates $65 \mathrm{~N}, 00 \mathrm{E}$ (Building E5974 coordinates) that is buried at a depth of approximately $3 \mathrm{ft}$. It is believed that this reflector is a natural sand lens. This sand lens can be seen in other southnorth and west-east profiles; however, it is the most prominent feature in the profile shown in Figure 6. 


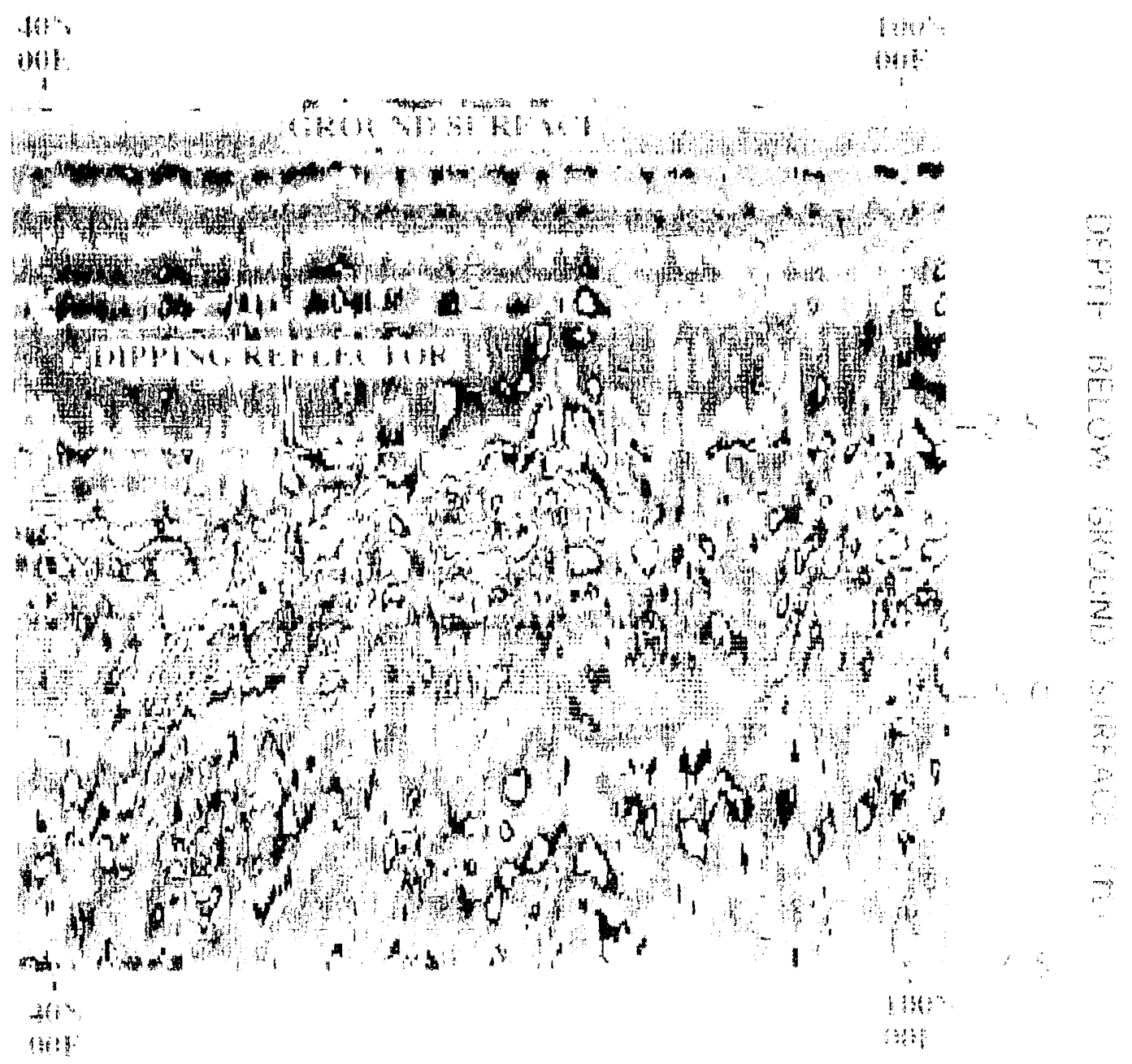

FIGURE 6 South North Ground Pentetrating Radar Profile for the Area West of Building E5974 (The location of this profile is shown in Figure 3 as line No. 3. ) 


\section{Discussion}

Magnetic and resistivity anomalies are superimposed on the map shown in Figure 7. The major magnetic anomalies, with three exceptions, are all contained within or on the borders of the most electrically conductive zone of the site, which strongly suggests that this is an area of construction fill material. The spatial relationship of small magnetic sources lying within a broad conductive background is a common characteristic around buildings and roads in the Canal Creek area. The conductive and magnetic area is also the area where several large surface depressions were observed, which are probably due to differential subsidence, collapse of cavities, and compaction of the fill. The conductive fringe along much of the southern boundary of the site is produced by fill brought in for road grade.

Exceptions to the magnetic/conductive relationship are observed in the northwest quadrant of the survey area. Three multipoint magnetic anomalies in this high-resistivity zone are not associated with conductive features, nor are they due to natural geologic causes. These isolated magnetic sources, occurring in an otherwise undisturbed background, do not have the same characteristics as the smaller, construction-fill-type anomalies; rather, they have characteristics similar to the anomalies associated with the railroad tracks and surface debris. The dimensions of the anomalies suggest that they are caused by a single large source or a combination of near-surface small sources. The appearance of the GPR and electrical anomalies rules against near-surface drums or tanks being the cause.

The GPR data do not reveal any anomalies of great significance; however, a strong reflector was observed in the northwest corner of the survey area. This reflector can be correlated with a high-resistivity anomaly detected in the same area and is most likely the result of a natural sand lens. 


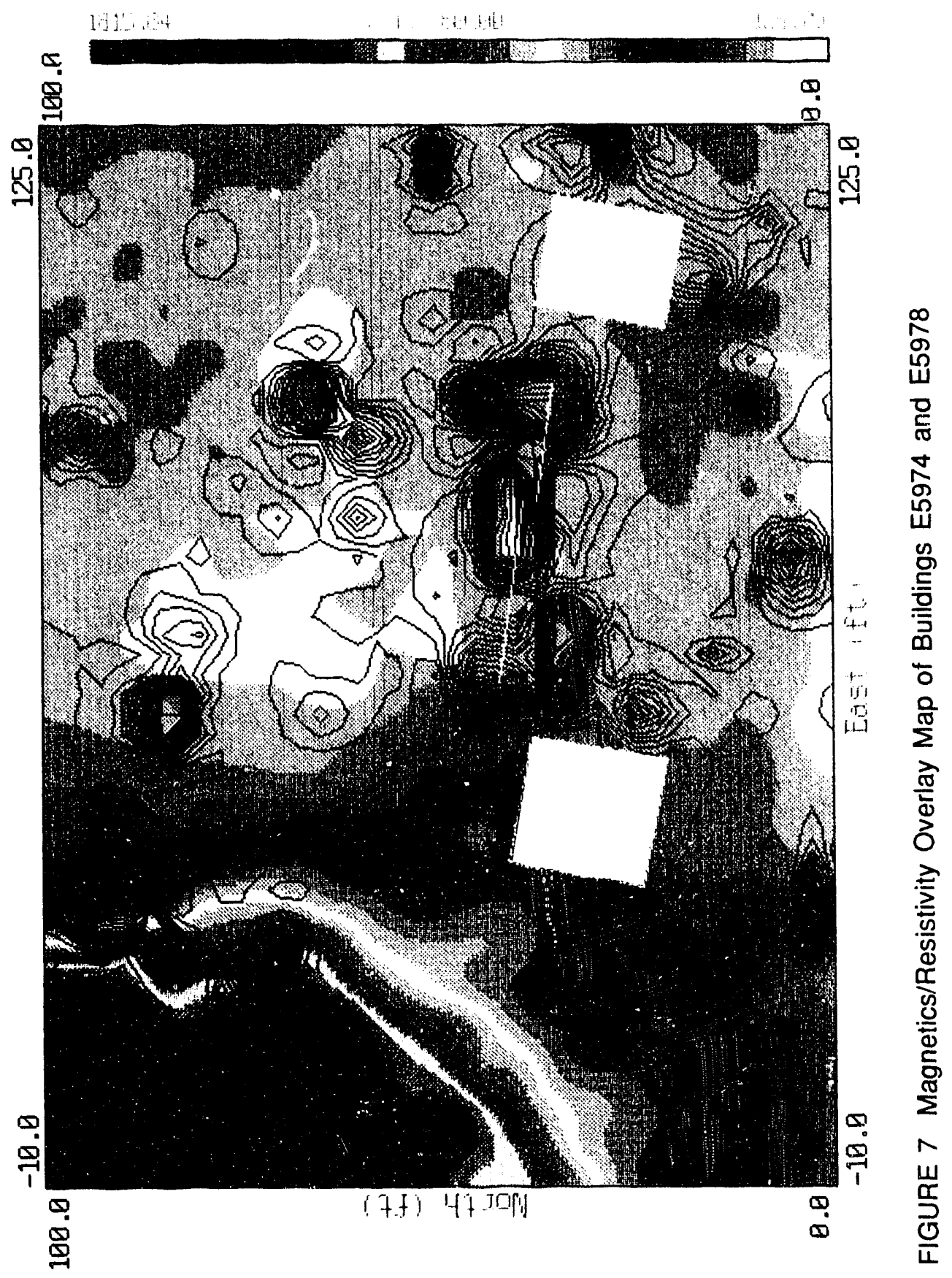




\section{Conclusions} following:

Specific conclusions drawn from the surveys of Buildings E5974 and E5978 are the

1. Magnetic anomalies between the buildings and along Hog Point Road are believed to be associated with construction fill and road-grade material.

2. Three magnetic anomalies in the high-resistivity, northwest quadrant of the survey area have unidentified sources.

3. High resistivities in the west/northwest quadrant are believed to be due to natural causes; however, an electrical depth-sounding station centered in this zone indicates a layer rising to $3,055 \Omega-\mathrm{m}$. A value this high in a wetland environment is not completely understood, but the GPR data indicate that this reflector may be a sand lens. Core samples taken from the northwest quadrant would satisfy questions pertaining to the source of this unusual feature.

4. There are no magnetic, electrical, or GPR anomalies immediately surrounding the buildings that would suggest the presence of buried pipes, drains, or tanks. 


\section{References}

AEHA: see U.S. Army Environmental Hygiene Agency.

EAI Corporation, 1989, Historical Records Search and Site Survey of Edgewood Area Buildings, Final Report, prepared for U.S. Army Chemical Research, Development, and Engineering Center, Aberdeen Proving Ground, Md., under contract No. DAA15-87-D0021.

Geophysical Survey Systems, Inc., 1987, Operations Manual for Subsurface Interface Radar (SIR System-3).

Golden Software, Inc., 1991, SURFER Version 4, Golden, Colo.

Interpex Limited, 1988, RESIX PLUS User's Manual, Golden, Colo.

Keller, G.V., and F.C. Frischknecht, 1970, Electrical Methods in Geophysical Prospecting, Pergamon Press, New York, N.Y.

McGinnis, L.D., and S.F. Miller, 1991, Interim Progress Report - Geophysics: Building E5032 Decommissioning, Aberdeen Proving Ground, report ANL/ESD/TM-20, Argonne National Laboratory, Argonne, Ill.

McGinnis, L.D., S.F. Miller, M.G. McGinnis, and M.D. Thompson, 1992, unpublished information, Argonne National Laboratory, Argonne, Ill.

Munsell Soil Color Charts, 1975, Macbeth, a division of Kollmorgen Corp., Baltimore, Md.

Oliveros, J.P., and P. Gernhardt, 1989, Hydrogeologic Data for the Canal Creek Area, Aberdeen Proving Ground, Maryland, April 1986-March 1988, U.S. Geological Survey Open-File Report 89-387.

U.S. Army Environmental Hygiene Agency, 1989, RCRA Facility Assessment Report, Edgewood Area, Aberdeen Proving Ground, Maryland. 
Appendix A:

Electrical Depth-Sounding Curves 


\section{Appendix A: \\ Electrical Depth-Sounding Curves}

Four Schlumberger electrical depth soundings near buildings in the Edgewood area provide a depth dimension to resistivities of soils, sediment, and anomalous unidentified materials. Soundings were made near Buildings E5282, E5440, E5481, and E5974. Locations of centers of stations and orientations of electrode arrays are listed in Table A.1, and the curves are shown at the end of Appendix A as Figures A.1-A.4.

Inversion of these curves using the Interpex code, RESIX PLUS (Interpex Limited 1988), indicates that resistivity of dry soils is from 200 to $300 \Omega-\mathrm{m} ;{ }^{*}$ saturated sediments, about $100 \Omega-\mathrm{m}$; saturated, organic-rich sediments, about $200 \Omega-\mathrm{m}$; and anomalous materials range from less than 10 to $10,000 \Omega-\mathrm{m}$. Maximum current electrode spacings $(A B / 2)$ ranged from 40 to $100 \mathrm{~m}$, providing information to depths of about $50 \mathrm{~m}$.

Normal undisturbed curves were observed at Buildings E5282 and E5481. These stations were located in topographically low areas where the water table lies within $3 \mathrm{~m}$ of the surface.

A reasonable interpretation of the curve at Building E5440, which was centered in an open area northeast of the building, is not feasible without more historical information about the site. Former roads, landfills, and other subsurface artifacts could explain the orders of magnitude change in resistivity values from $15 \Omega-\mathrm{m}$ to $10,000 \Omega-\mathrm{m}$ at a depth of $11 \mathrm{~m}$.

TABLE A.1 Location of Centers of Stations and Orientations of Electrode Arrays for Schlumberger Electrical Depth Soundings at APG

\begin{tabular}{lcc}
\hline \multicolumn{1}{c}{ Station Center } & $\begin{array}{c}\text { Array } \\
\text { Orientation }\end{array}$ & $\begin{array}{c}\text { Maximum } \\
\text { Electrode } \\
\text { Spacing } \\
(\mathrm{m})\end{array}$ \\
\hline $\begin{array}{l}\text { Northeast of Building E5282 } \\
\text { Northeast of Building E5440 }\end{array}$ & NW-W & 50 \\
$\begin{array}{l}\text { North of Building 5481 } \\
\text { Northwest of Building E5974 }\end{array}$ & NW-W & 40 \\
\hline
\end{tabular}

\footnotetext{
* Electrical depth soundings were measured in the unit of $\Omega$-meter. Thus, discussion of electrical depth soundings in this report gives depths measured in meters. To convert from meters to feet, multiply depths in meters by 3.28 .
} 
The sounding curve at Building E5974 displays the most unusual surface resistivities. A 2.7 - $\mathrm{m}$-thick layer of extraordinarily high resistivity $(3,055 \Omega-\mathrm{m})$ near the surface is underlain by a layer having a higher than normal value $(440 \Omega-\mathrm{m})$ extending to a depth of $50 \mathrm{~m}$. This is underlain by a layer having normal resistivities of near $123 \Omega-\mathrm{m}$.

Earth resistivity models calculated from inversion of the sounding curves are shown in Table A.2.

TABLE A.2 Resistivity Models Calculated from Electrical Depth Soundings

\begin{tabular}{lccc}
\hline Station & $\begin{array}{c}\text { Resistivity } \\
(\Omega-m)\end{array}$ & $\begin{array}{c}\text { Thickness } \\
(\mathrm{m})\end{array}$ & $\begin{array}{c}\text { Depth } \\
(\mathrm{m})\end{array}$ \\
\hline E5282 & 108 & 0.4 & 0.4 \\
& 244 & 4.5 & 4.9 \\
& 95 & unknown & unknown \\
E5440 & 269 & 1.2 & 1.2 \\
& 14 & 10.1 & 11.3 \\
& 11,525 & unknown & unknown \\
E5481 & 366 & 4.1 & 4.1 \\
& 105 & unknown & unknown \\
& & & 0.9 \\
E5974 & 783 & 0.9 & 0.9 \\
& 3.055 & 2.7 & 3.6 \\
& 440 & 46.4 & 50.0 \\
& 123 & unknown & unknown \\
& & & \\
\hline
\end{tabular}



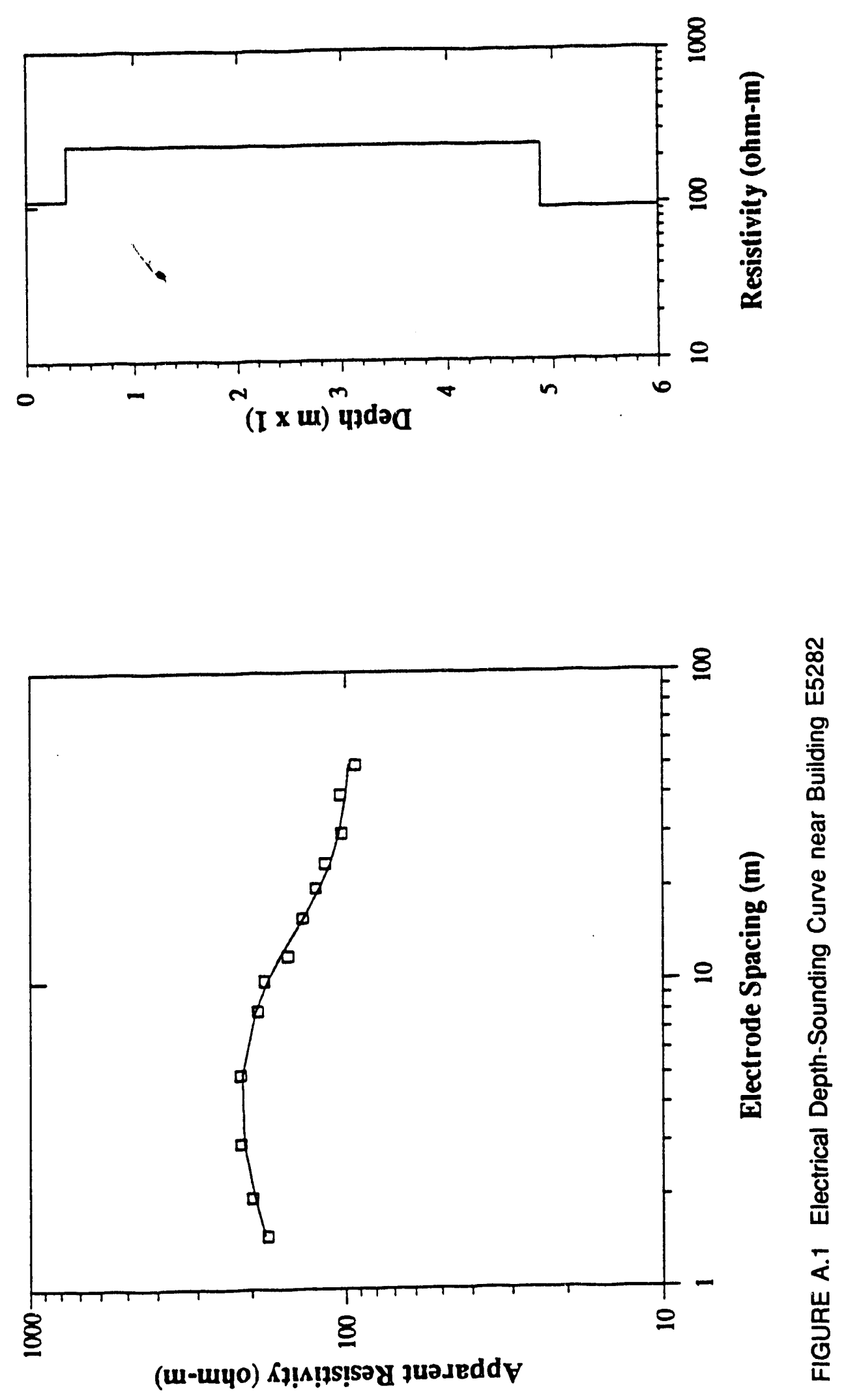


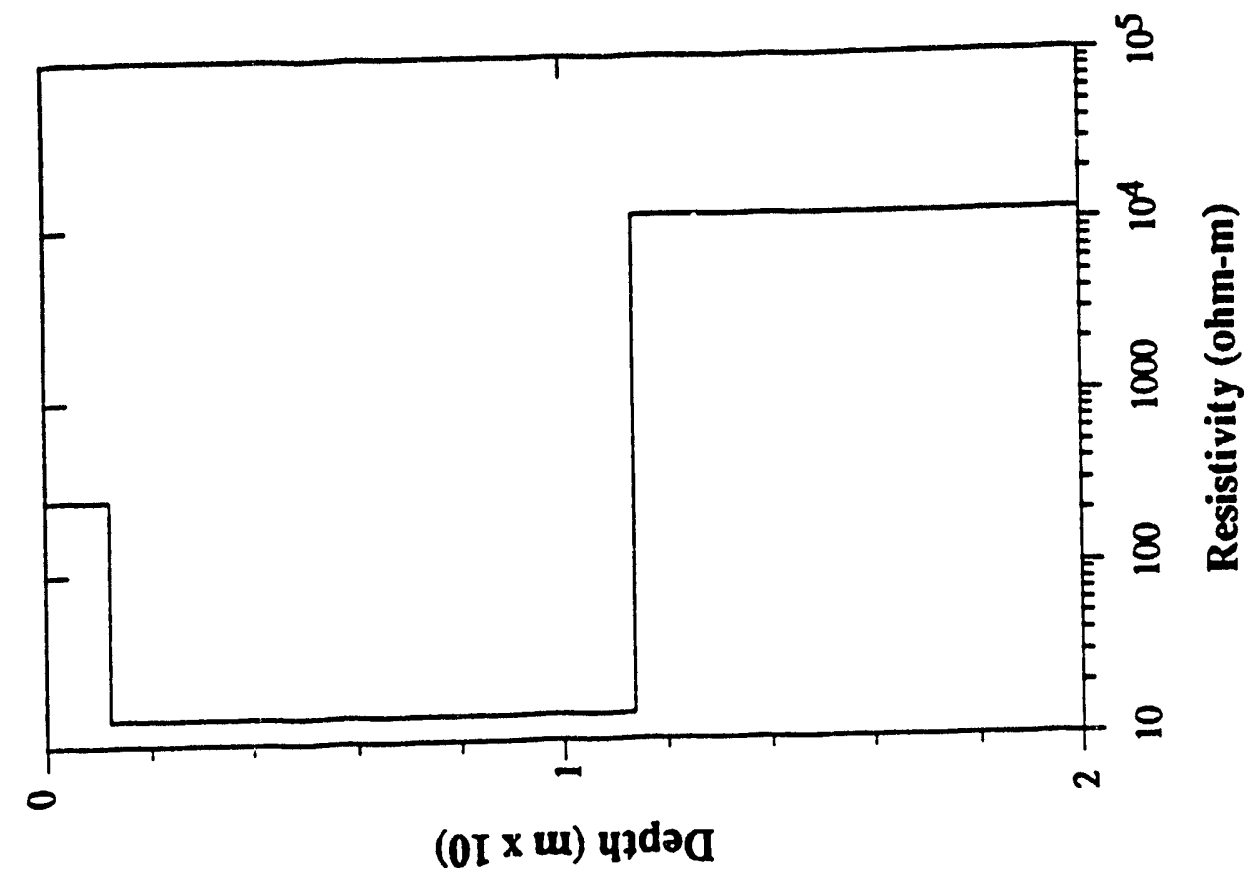

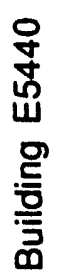

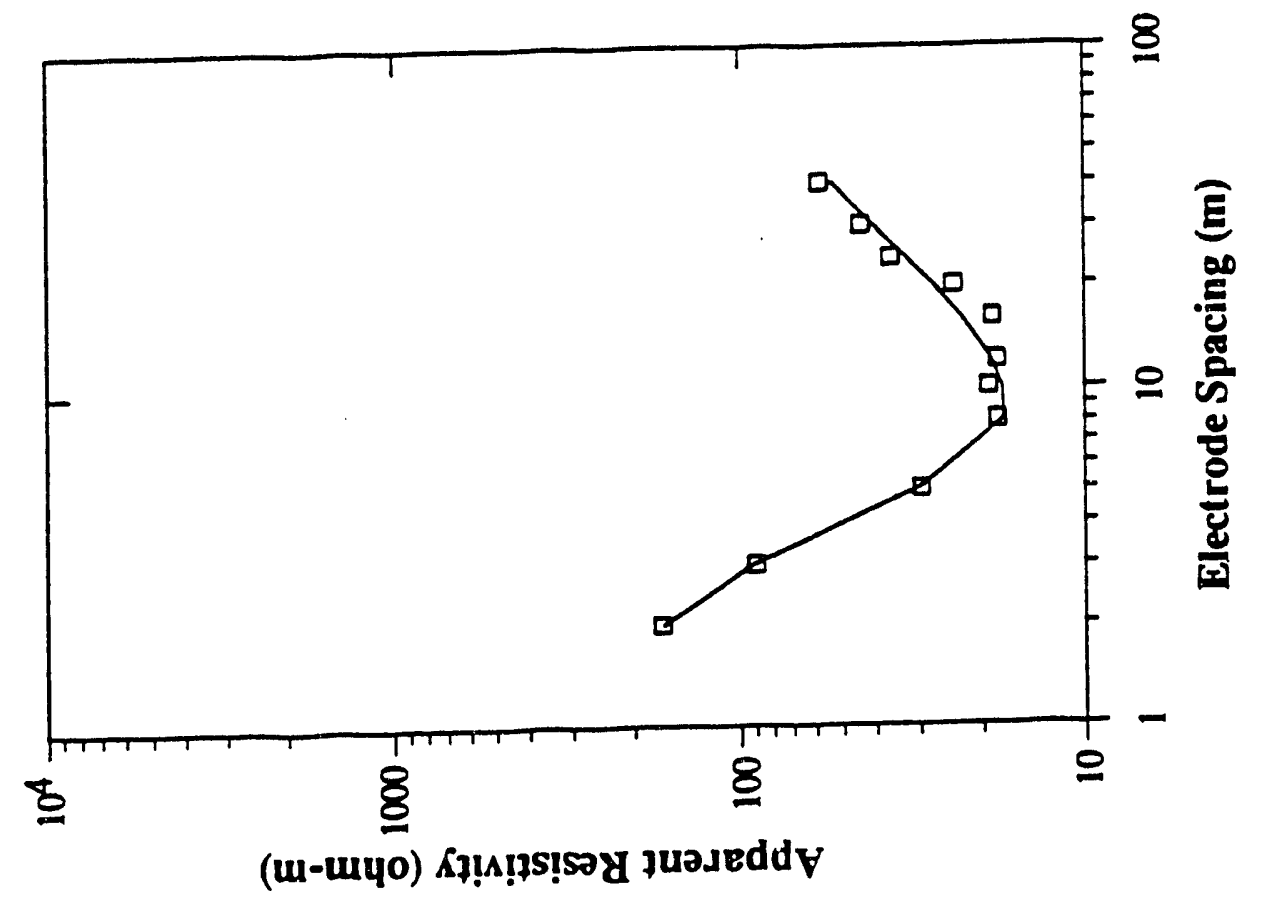

ธ్ర

E

方

으

등

\&

홍

중

은

픈

$\stackrel{4}{4}$

峁 

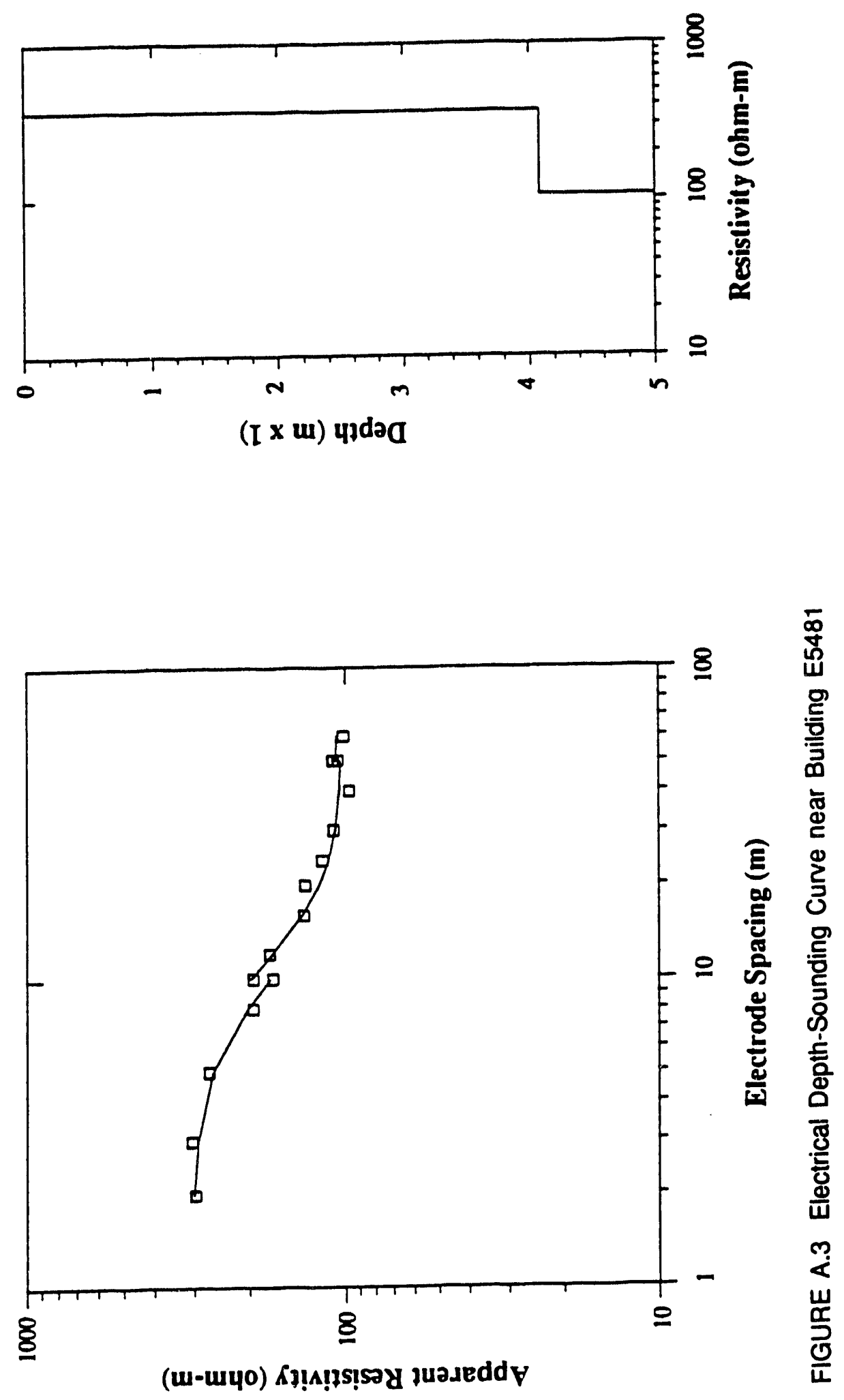

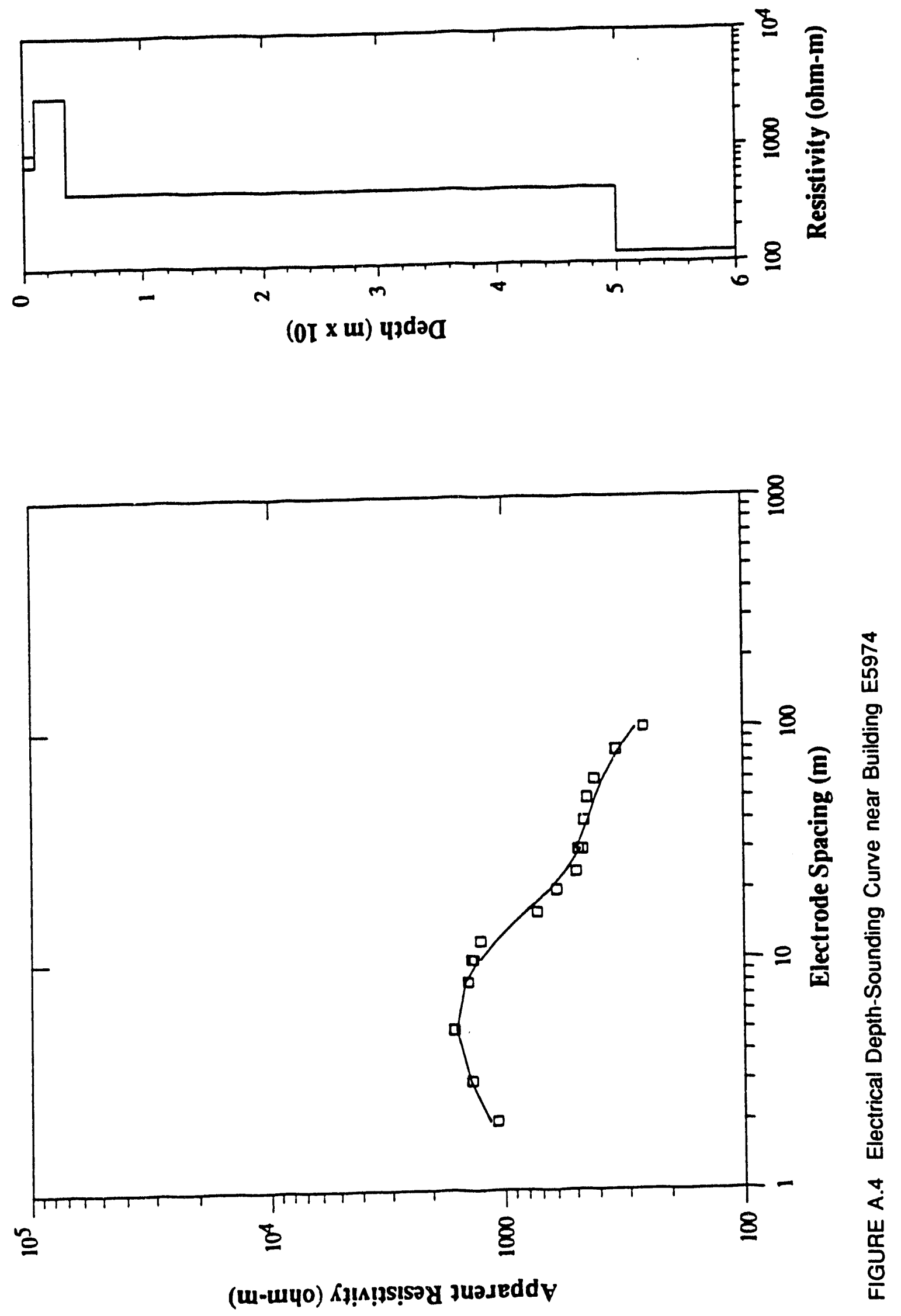
Appendix B:

Ground-Penetrating Radar Line Coordinates 


\section{Appendix B:}

\section{Ground-Penetrating Radar Line Coordinates}

\section{Building E5974}

\begin{tabular}{|c|c|c|c|c|}
\hline \multirow{2}{*}{$\begin{array}{l}\text { Line } \\
\text { No. }\end{array}$} & \multicolumn{2}{|c|}{$\begin{array}{c}\text { Start } \\
\text { Coordinates } \\
\end{array}$} & \multicolumn{2}{|c|}{$\begin{array}{c}\text { End } \\
\text { Coordinates }\end{array}$} \\
\hline & North & East & North & East \\
\hline 1 & 00 & 00 & 100 & 00 \\
\hline 2 & 00 & 05 & 100 & 05 \\
\hline 3 & 00 & 10 & 100 & 10 \\
\hline 4 & 00 & 15 & 100 & 15 \\
\hline 5 & 41 & 20 & 100 & 20 \\
\hline 6 & 43 & 25 & 100 & 25 \\
\hline 7 & 45 & 30 & 100 & 30 \\
\hline 8 & 45 & 35 & 100 & 35 \\
\hline 9 & 45 & 40 & 100 & 40 \\
\hline 10 & 43 & 45 & 100 & 45 \\
\hline 11 & 25 & 50 & 100 & 50 \\
\hline 12 & 00 & 55 & 100 & 55 \\
\hline 13 & 00 & 60 & 43 & 60 \\
\hline 14 & 00 & 70 & 44 & 70 \\
\hline 15 & 00 & 75 & 50 & 75 \\
\hline 16 & 00 & 80 & 100 & 80 \\
\hline 17 & 00 & 00 & 00 & 80 \\
\hline 18 & 05 & 00 & 05 & 80 \\
\hline 19 & 10 & 00 & 10 & 80 \\
\hline 20 & 15 & 00 & 15 & 80 \\
\hline 21 & 65 & 00 & 65 & 52 \\
\hline 22 & 85 & 00 & 85 & 100 \\
\hline 23 & 90 & 00 & 90 & 100 \\
\hline 24 & 95 & 00 & 95 & 100 \\
\hline 25 & 100 & 00 & 100 & 100 \\
\hline
\end{tabular}

\section{Building E5978}

\begin{tabular}{rrrrrr}
\hline & \multicolumn{2}{c}{$\begin{array}{c}\text { Start } \\
\text { Coordinates }\end{array}$} & & \multicolumn{2}{c}{$\begin{array}{c}\text { End } \\
\text { Coordinates }\end{array}$} \\
No. & North & East & North & East \\
& & & & & \\
1 & 00 & 45 & 100 & 45 \\
2 & 80 & 45 & 100 & 45 \\
3 & 00 & 40 & 100 & 40 \\
4 & 37 & 35 & 95 & 35 \\
5 & 40 & 30 & 110 & 30 \\
6 & 40 & 25 & 100 & 25 \\
7 & 35 & 20 & 100 & 20 \\
8 & 28 & 15 & 100 & 15 \\
9 & 00 & 10 & 100 & 10 \\
10 & 00 & 05 & 100 & 05 \\
11 & 00 & 00 & 100 & 00 \\
12 & 100 & 45 & 100 & 00 \\
13 & 75 & 45 & 75 & 00 \\
14 & 55 & 45 & 55 & 00 \\
15 & 10 & 45 & 10 & 00 \\
16 & 05 & 45 & 05 & 00 \\
17 & 00 & 45 & 00 & 00 \\
& & & & \\
\hline & & & &
\end{tabular}



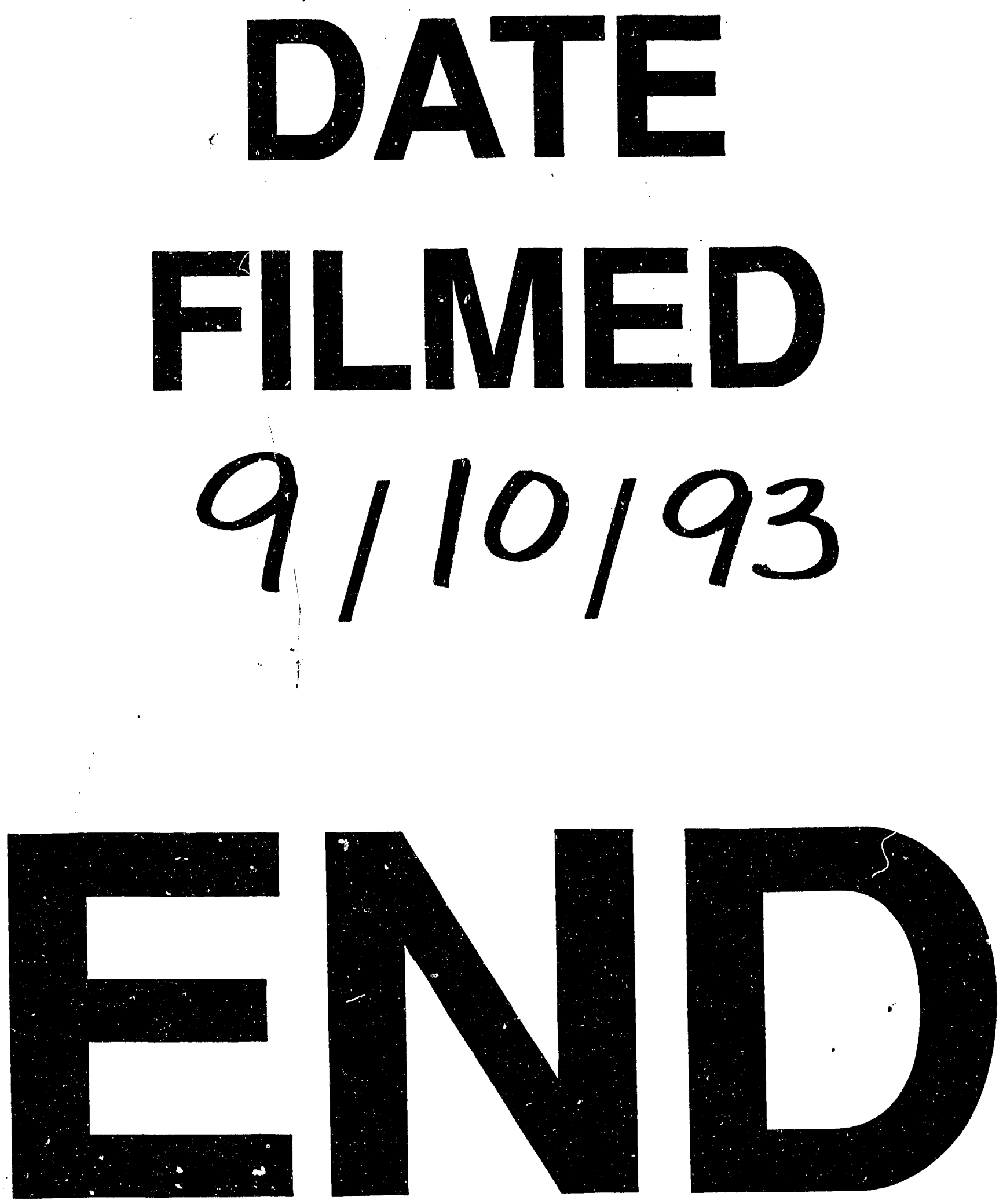
